\title{
Klasifikasi Pola Kain Tenun Melayu Menggunakan Faster R-CNN
}

\author{
Yoze Rizki ${ }^{1}$, Reny Medikawati Taufiq ${ }^{2}$, Dinia Putri ${ }^{3}$, Harun Mukhtar ${ }^{4}$ \\ Teknik informatika, Fakultas Ilmu Komputer, Universitas Muhammadiyah Riau ${ }^{1,2,3,4}$ \\ yozerizki@umri.ac.id ${ }^{1}$, renymedikawati@umri.ac.id², diniaputri915@gmail.com ${ }^{3}$, \\ harunmukhtar@umri.ac.id ${ }^{4}$
}

\section{Article Info \\ History : \\ Dikirim 12 November 2020 \\ Direvisi 14 Desember 2020 \\ Diterima 6 Januari 2021}

\section{Kata Kunci : \\ Classification Computer Vision \\ Deep learning \\ Faster R-CNN \\ Tenun}

\begin{abstract}
Abstrak
Motif tenun melayu sangat beragam. Keberagaman ini membuat sulit membedakan motif-motif kain tenun tersebut. Klasifikasi data diperlukan untuk mengidentifikasi karakteristik objek yang terkandung dalam basis data agar kemudian dikategorikan ke dalam kelompok yang berbeda. Faster R-CNN dengan model arsitektur VGG dipilih untuk merancang sebuah sistem untuk klasifikasi motif tenun melayu. Faster R-CNN mengeliminasi sangat banyak waktu training karena mengeliminasi algoritma selective search untuk mencari region proposal. Diluar kecepatan tersebut, permasalahan lain yang muncul adalah bagaimana performa Faster R-CNN dalam mengklasifikasi citra motif tenun dibandingkan algoritma region proposal yang lain. Tujuan penelitian yang dicapai dalam penelitian ini yaitu untuk mengetahui performa klasifikasi motif tenun melayu menggunakan Faster R-CNN dengan model arsitektur VGG, dengan cara mengukur persentase akurasi, presisi, dan recall yang akan divalidasi menggunakan K-Fold Cross Validation. Jumlah dataset yang digunakan berjumlah 100 citra yang diacak untuk masingmasing dari 5 (lima) fold pada K-fold cross validation. Data tersebut dibagi menjadi 80 data train dan 20 data test. Setelah dilakukan persiapan data, pre-processing, serta implementasi, dilakukan pengujian dengan hasil bahwa dari data latih yang berupa citra kain tenun melayu, didapatkan skor rata-rata training loss dari step pertama hingga step terakhir sebesar 1,915. Klasifikasi karakteristik pengenalan motif tenun melayu menggunakan Metode deteksi objek Faster R-CNN melalui validasi K-Fold Cross Validation dengan nilai $\mathrm{k}=5$, didapatkan akurasi $82.14 \%$, presisi $91.38 \%$ dan recall $91.36 \%$. Dari Analisa ditemukan bahwa Faster R-CNN dengan VGG secara keseluruhan unggul dibandingkan algoritma lain (CNN dengan arsitektur AlexNet), karena dipengaruhi perbedaan arsitektur dan sedikit dipengaruhi oleh pemilihan algoritma.
\end{abstract}

(C) This work is licensed under a Creative Commons AttributionShareAlike 4.0 International License.

\footnotetext{
Koresponden:

Yoze Rizki

Program Studi Teknik Informatika, Fakultas Ilmu Komputer

Universitas Muhammadiyah Riau,

Jl. Tuanku Tambusai, Pekanbaru,Indonesia, 28290

Email : yozerizki@umri.ac.id
} 


\section{PENDAHULUAN}

Tenun adalah sejenis kain tertentu yang dibuat khusus dengan motif-motif yang khas. Sementara motif adalah desain yang dibuat dari bagian-bagian bentuk, berbagai macam garis atau elemen-elemen [1]. Motif tenun melayu sangat beragam. Keberagaman ini membuat sulit membedakan motif-motif kain tenun tersebut. Pada umumnya masyarakat tidak terlalu mengenali motif-motif tenun melayu tetapi masyarakat pada umumnya hanya melihat keindahan motif tenun melayu saja. Oleh sebab itu diperlukan inovasi teknologi pengenalan motif yang dapat mengenali motif-motif tenun melayu.

Deep learning dibutuhkan untuk menganalisa dan mengklasifikasi citra motif tenun dengan akurasi yang tinggi. Deep learning terbagi dalam dua sesi yaitu sesi training dan testing [2]. Pada sesi training, ekstrasi fitur dari setiap data dipelajari, sehingga suatu label dengan label yang lain dapat dibedakan. Sementara pada sesi testing data-data yang diuji dapat dianalisa dari hasil sesi training.

Beberapa algoritma deep learning klasik yang dapat digunakan untuk klasifikasi citra diantaranya, K-NN [3], SVM [4], Ensemble Learning algorithm [5], Multi-layer Perceptron (MLP) [6], dan CNN [7]. Dewasa ini terdapat dua kelompok algoritma object detector modern, yaitu kelompok region proposal seperti R-CNN [8], Fast R-CNN [9], Faster R-CNN [10] dan kelompok single shot seperti You only look once (YOLO) [11], [12] dan Single shot Detector (SSD) [13]. Dari penelitian yang dilakukan [14] dapat dilihat bahwa algoritma-algoritma Single shot jauh lebih cepat dibandingkan region proposal, namun tidak lebih akurat. Sementara hasil yang diharapkan pada klasifikasi motif tenun melayu adalah mendapatkan nilai akurasi tinggi, bukan kecepatan yang tinggi.

Terdapat beberapa penelitian yang telah dilakukan menggunakan deep learning dengan tema indentifikasi pola kain, seperti yang dilakukan oleh oleh [7], [15], yang dibuat dengan Convolutional neural network (CNN), Metode K-Nearest Neighbor (K-NN) [16], [17], dan Support vector machine (SVM) [18]. Namun penelitian yang paling relevan dengan penelitian ini adalah penelitian yang dilakukan oleh [19] pada tahun 2019 berjudul Pengenalan pola motif kain tenun gringsing menggunakan metode CNN dengan model arsitektur alexnet. Pengujian dilakukan untuk mendapatkan performa sistem terkait waktu training, akurasi, presisi, recall, dan nilai f-measure. Berdasarkan hasil pengujian, model yang dibangun berhasil menyelesaikan waktu training selama 19.33 jam, dan memiliki akurasi $76 \%$, presisi $74.1 \%$, dan recall $72.3 \%$, serta nilai F-measure sebesar $0.73[19]$.

Faster R-CNN [10] dengan model arsitektur VGG [20] dipilih untuk merancang sebuah sistem untuk klasifikasi motif tenun melayu. Data yang digunakan berupa citra dua dimensi yang merupakan barisan matrix pixel berbentuk grid. Data berbentuk grid sangat relevan untuk penerapan metode $C N N$. Walaupun Faster R-CNN tidak akan secepat algoritma single shot yang tidak mengenal region proposal, Faster R-CNN mengeliminasi sangat banyak waktu training karena Faster R-CNN hanya butuh 300 proposal per citra sementara [8] and [9] memerlukan 2000 proposal. Hal ini terjadi karena Faster R-CNN mengeliminasi algoritma selective search yang digunakan R-CNN [8] dan Fast RCNN [9] untuk mencari region proposal dan sebagai gantinya membiarkan jaringan neural network melakukan pembelajaran terhadap region proposal. Diluar semua pembahasan mengenai kecepatan komputasi, permasalahan lain yang muncul adalah bagaimana performa Faster R-CNN dalam mengklasifikasi citra motif tenun dibandingkan algoritma region proposal yang lain.

Tujuan penelitian yang dicapai dalam penelitian ini yaitu untuk mengetahui performa pengenalan dan klasifikasi motif tenun melayu menggunakan Faster R-CNN, dengan cara mengukur persentase dari tingkat akurasi, presisi, dan recall yang akan divalidasi menggunakan K-Fold Cross Validation.

\section{METODE PENELITIAN}

Bagian ini mengurai tentang analisis kebutuhan sistem, pengumpulan dataset, perancangan pre-processing, dan training Faster R-CNN.

Untuk tahap awal, kebutuhan awal penelitian dipersiapkan. Kebutuhan ini termasuk sampel dataset kain tenun, sistem perangkat keras berupa komputer, dan library perangkat lunak yang digunakan untuk kebutuhan training data. 
Pengumpulan Dataset berupa citra di dapat dari pengambilan gambar kain motif tenun melayu dan crawling pada internet. Dataset ini terdiri dari berbagai citra kain tenun melayu sebagai data training dan data test. Keberagaman data sangat disarankan untuk memperoleh hasil pembelajaran sistem yang lebih baik.

Pada penelitian ini dideteksi 2 sampel motif tenun melayu yaitu Pucuk Rebung \& Siku Keluang. Pemilihan kedua motif ini didasari kebutuhan penelitian untuk mengklasifikasi lebih dari satu jenis, dan keberagaman dataset yang tersedia untuk kedua jenis motif diatas. sistem yang akan dibuat adalah berbasis desktop, dengan jumlah dataset yang digunakan berjumlah 100 citra yang akan diacak untuk setiap fold pada K-fold cross validation sebanyak 5 (lima) fold. Data tersebut dibagi menjadi data training dan data testing. Data citra yang digunakan untuk proses training berjumlah 80 data terdiri dari 40 citra pucuk rebung dan 40 citra siku keluang yang dilabeli di tiap citra. Data citra yang digunakan untuk proses testing berjumlah 10 citra pucuk rebung dan 10 citra siku keluang yang dilabeli di tiap citra.

Diagram alur penelitian dapat dilihat pada gambar 1:

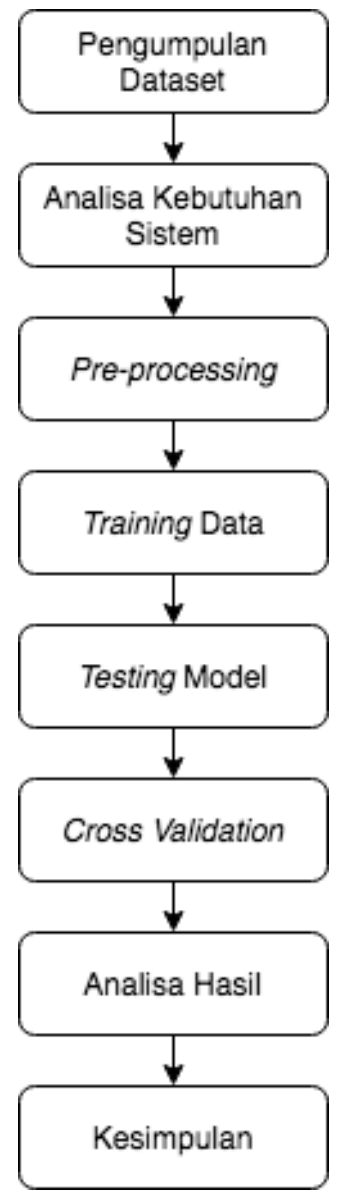

Gambar 1. Alur Penelitian

Setelah mengumpulkan dataset, selanjutnya dilakukan pre-processing citra dataset. Hal pertama yang dilakukan pada proses pre-processing adalah penyeragaman ukuran pixel seluruh citra dataset dengan pixel 800x600 pixel. Proses pre-processing lainnya yaitu augmentasi data dengan cara memberikan distorsi pada citra sampel, dan berkas hasilnya dimasukkan kedalam dataset. Preprocessing yang terakhir yaitu Pelabelan Citra.

Pelabelan citra adalah tahap awal dimana dataset input diberikan label atau pengenal (tanda) dengan tujuan untuk menyimpan informasi citra yang selanjutnya disimpan dalam berkas XML dengan format PASCAL VOC. Pelabelan dilakukan secara manual terhadap 100 dataset citra motif tenun melayu pucuk rebung dan siku keluang menggunakan labelImg seperti dapat dilihat pada gambar 2. 


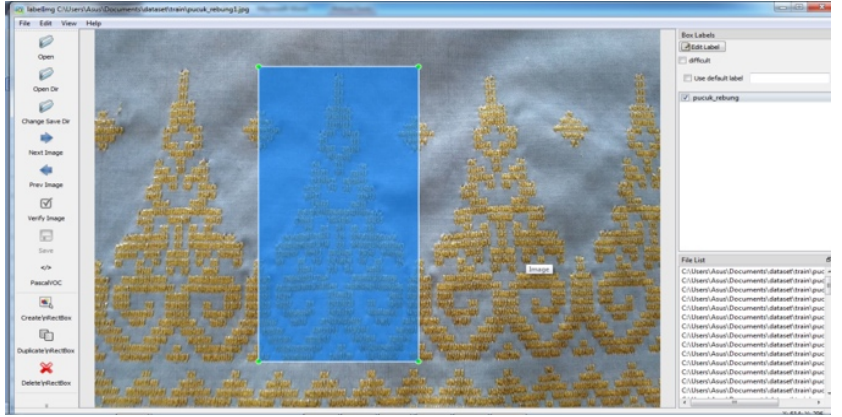

Gambar 2. Proses Pelabelan Citra Motif Tenun Melayu Pucuk Rebung

Setelah dilakukan pelabelan perlu adanya konversi berkas dari XML ke CSV untuk tujuan konversi dataset ke berkas 'Annotation.txt'. Setelah proses konversi berkas XML dengan output berupa file CSV diperlukan konversi ke 'Annotation.txt' file yang digunakan untuk feeding data pada proses training.

Convolutional neural network (CNN) yang akan digunakan untuk memproses citra tenun melayu merupakan jaringan saraf yang dikhusukan untuk memproses data yang memiliki grid [21]. Pada penelitian ini, data yang digunakan berupa citra motif tenun melayu. Citra dua dimensi merupakan barisan matrix pixel berbentuk grid. Data berbentuk grid sangat relevan untuk penerapan metode Convolutional neural network atau dikenal juga dengan sebutan ConvNets. Convolutional neural network memiliki beberapa layer yang difungsikan untuk melakukan filter pada setiap prosesnya. Prosesnya disebut dengan proses training. Pada proses training terdapat 3 tahapan yaitu Convolutional layer, Pooling layer, dan Fully connected layer [22]. Ilustrasi arsitektur CNN dapat dilihat pada Gambar 3.

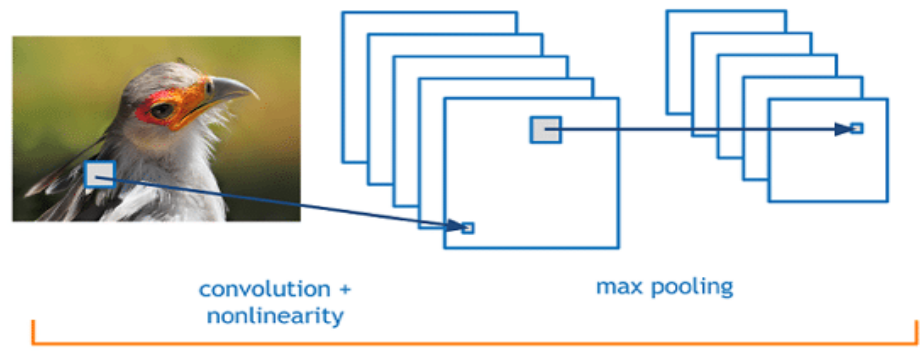

convolution + pooling layers

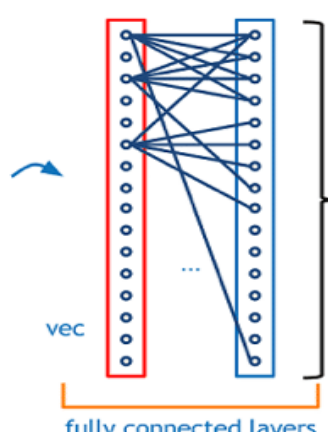

fully connected layers

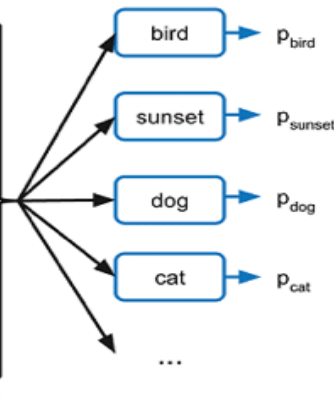

Nx binary classification

Gambar 3. Arsitektur Convolutional Neural Network [22]

Proses konvolusi Pada Convolutional layer adalah proses dimana matriks kernel yang memiiki fungsi melakukan filter pada matriks citra [23]. Pooling atau subsampling adalah pengurangan ukuran matriks dengan menggunakan operasi pooling. Pooling layer biasanya dilakukan setelah convolution Layer. Proses konvolusi dan pooling dilakukan beberapa kali sehingga didapatkan peta fitur (feature map) dengan ukuran yang dikehendaki. Peta fitur tersebut akan menjadi input bagi fully connected neural network yang akan mengklasifikasi nilai output. Convolutional neural networks (ConvNets) merupakan penerapan dari Artificial Neural networks (ANN) yang lebih istimewa dan saat ini diklaim sebagai model terbaik untuk memecahkan masalah pengenalan objek.

Pengenalan pola motif citra tenun pada penelitian ini dilakukan menggunakan salah satu metode convolutional neural network yaitu Faster R-CNN. Faster R-CNN merupakan metode deep learning yang digunakan untuk mengenali suatu suatu objek pada citra [24]. Pengenalan dilakukan dengan menelusuri ciri-ciri yang dimiliki oleh objek pada citra. Penelusuran dilakukan melalui sejumlah layer (seperti yang dilakukan pada neural network) melalui proses konvolusi atau yang lebih dikenal dengan nama Convolutional neural network (CNN). 
Setelah melakukan konvolusi dan mendapatkan convolution layers, Region proposal Network diajukan untuk menentukan Region of interest yang akan digunakan sistem untuk menentukan kelas dari sebuah objek. Gambaran mengenai arsitektur dari Faster R-CNN dapat dilihat pada Gambar 4 berikut ini:

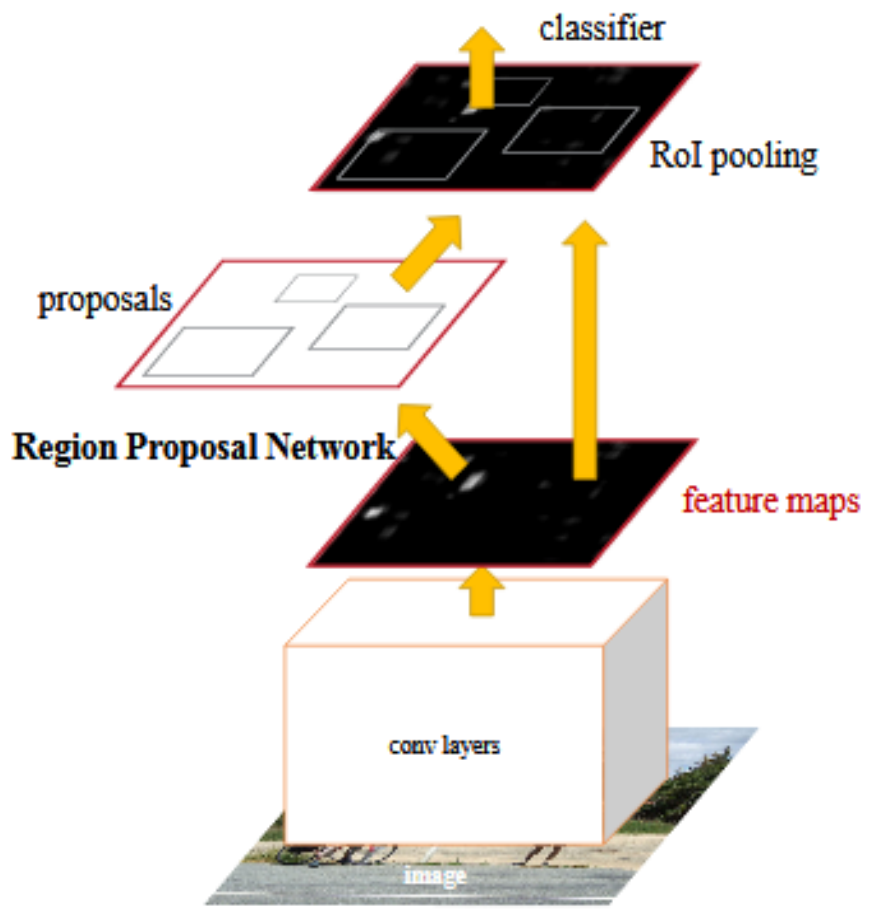

Gambar 4. Aristektur Faster R-CNN [24]

Pada implementasi sistem, tahap training data dengan algoritma Faster R_CNN adalah tahap utama, dimana Faster R-CNN dilatih untuk mempelajari suatu pola yang menghasilkan generator (nilai anchor). yang dapat dilihat pada gambar 5 .

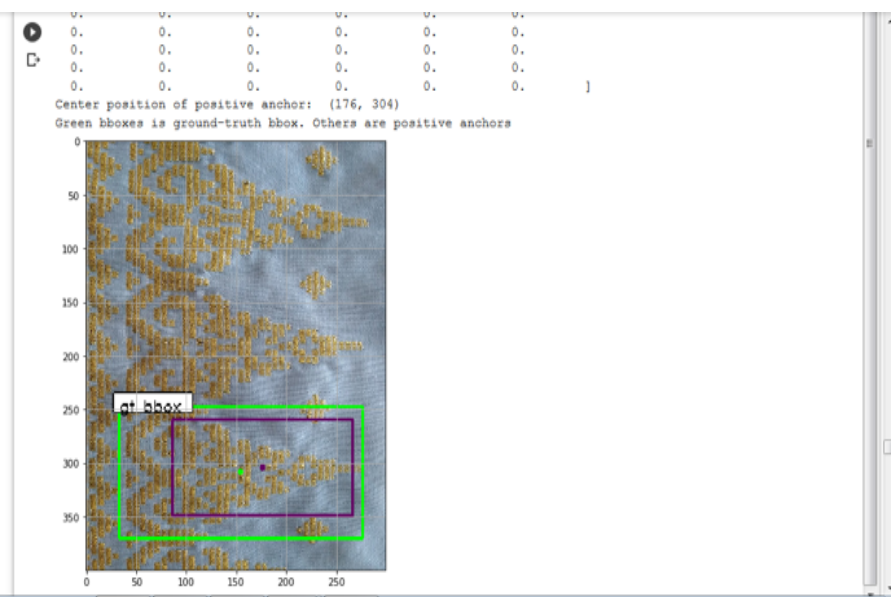

Gambar 5. Hasil Generator (Nilai Anchor.

\section{HASIL DAN PEMBAHASAN}

\subsection{Hasil}

Hasil implementasi dari proses pelatihan pada proses training merupakan sebuah model. Terdapat 3 tahapan yaitu Convolutional layer, Pooling layer, dan Fully connected layer [22]. Hasil 
akhir dari proses pembelajaran atau pelatihan Faster R-CNN adalah terbentuknya sebuah model dan record yang siap pakai untuk pendeteksian lebih lanjut atau dengan kata lain disebut dengan testing.

Pada proses training, loss merupakan penalti atau hukuman bagi sistem untuk prediksi yang salah. Dimana loss adalah angka yang menunjukkan indikasi seberapa buruk prediksi dari model dari sebuah sampel data. Jika prediksi model sempurna, maka loss akan bernilai nol. Sementara jika yang terjadi sebaliknya, maka jumlah loss lebih banyak. Tujuan dari training sebuah model adalah untuk mencari beban dan bias data yang memiliki loss rendah dalam rata-rata sebanyak jumlah data didalam dataset.

Gambar 6 merupakan grafik total loss yang dihasilkan pada saat melakukan proses training sampai dengan selesai sesuai dengan jumlah iterasi yang dilakukan yaitu sebanyak 40 langkah/steps. Dari data latih, didapatkan bahwa Ketika training epoch meningkat, skor training error akan menurun. Ini menunjukkan bahwa semakin banyak training yang dilakukan, sistem akan semakin terlatih untuk melakukan pengenalan atau identifikasi pola citra. Didapatkan bahwa score rata-rata nilai training loss dari step pertama hingga step terakhir adalah 1,915 .

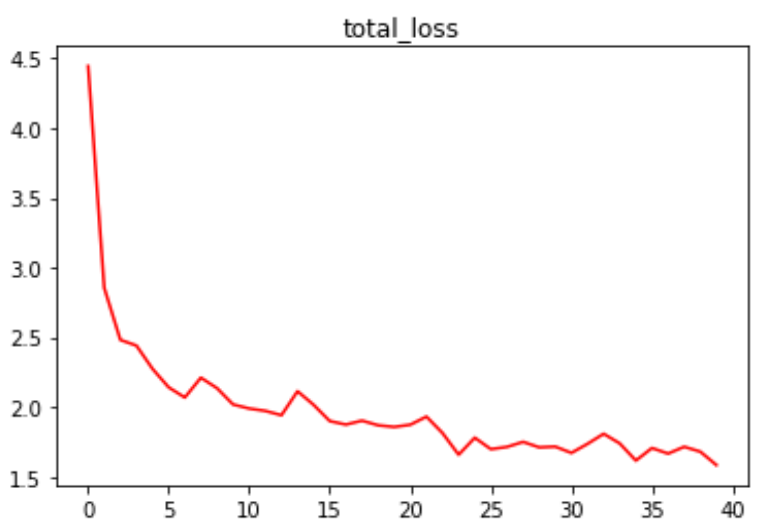

Gambar 6. Grafik Total Loss dari Faster R-CNN

Pengujian dilakukan untuk menentukan performa algoritma Faster R-CNN dengan cara mencari nilai akurasi, presisi dan recall dengan metode K-Fold Cross Validation. Pada pengujian ini dataset dibagi menjadi 5 folder yang masing-masing didalamnya terdapat 100 gambar dataset yang dibagi menjadi data train dan data test secara acak. Data train pada masing-masing dari kelima folder berjumlah 80 gambar, sedangkan data test berjumlah 20 gambar. Pada setiap fold dilakukan lima kali percobaan dan dihitung akurasinya.

Hasil pengujian dengan menggunakan $K$-Fold Cross Validation ini dapat dilihat pada Tabel 1 yang menampilkan akurasi, presisi, dan recall yang telah di kalkulasi pada masing-masing fold dengan perhitungan menggunakan Confussion Matrix. Confusion matriks adalah sebuah metode yang digunakan untuk menghitung nilai akurasi pada konsep data mining [25].

Tabel 1. Hasil Akurasi, Presisi, Recall Dengan Metode K-Fold Cross Validation

\begin{tabular}{cccccccc}
\hline \multirow{2}{*}{ No } & Fold & \multicolumn{3}{c}{ Faster R-CNN } & \multicolumn{2}{c}{ Metode lain (CNN) [19] } \\
\cline { 3 - 8 } & & Accuracy \% & Precision \% & Recall \% & Accuration \% & Precision \% & Recall \% \\
\hline $\mathbf{1}$ & 1 & $73 \%$ & $90 \%$ & $95 \%$ & $66 \%$ & $69 \%$ & $65 \%$ \\
\hline $\mathbf{2}$ & 2 & $91,30 \%$ & $95,20 \%$ & $95,20 \%$ & $80,10 \%$ & $73,20 \%$ & $75,20 \%$ \\
\hline $\mathbf{3}$ & 3 & $85,20 \%$ & $96,70 \%$ & $96,70 \%$ & $83,30 \%$ & $74,70 \%$ & $74,70 \%$ \\
\hline $\mathbf{4}$ & 4 & $76,10 \%$ & $87,50 \%$ & $87,50 \%$ & $74,10 \%$ & $78,50 \%$ & $69,50 \%$ \\
\hline $\mathbf{5}$ & 5 & $85,10 \%$ & $87,50 \%$ & $87,50 \%$ & $75,10 \%$ & $74,50 \%$ & $73,50 \%$ \\
\hline & Average $\%$ & $82,14 \%$ & $91,38 \%$ & $91,36 \%$ & $76.0 \%$ & $74.10 \%$ & $72.30 \%$
\end{tabular}


Confussion matrix merupakan sebuah tabel dengan empat kombinasi berbeda dari nilai prediksi dan nilai sebenarnya, True Positive (TP), True Negative (TN), False Positive (FP), dan False Negative (FN). Nilai true positive dan true negative adalah nilai pada titik dimana algoritma mengklasifikasi dengan benar, yaitu nilai true untuk TP atau nilai false untuk TN. Sementara false positive dan false negative, disisi lain, merupakan titik dimana algoritma salah mengklasifikasi.

Hasil pengujian akurasi yang dapat dilihat pada gambar 7 menyatakan bahwa algoritma deteksi objek Faster R-CNN dapat mengidentifikasi motif dari tenun melayu dengan nilai $82.14 \%$.

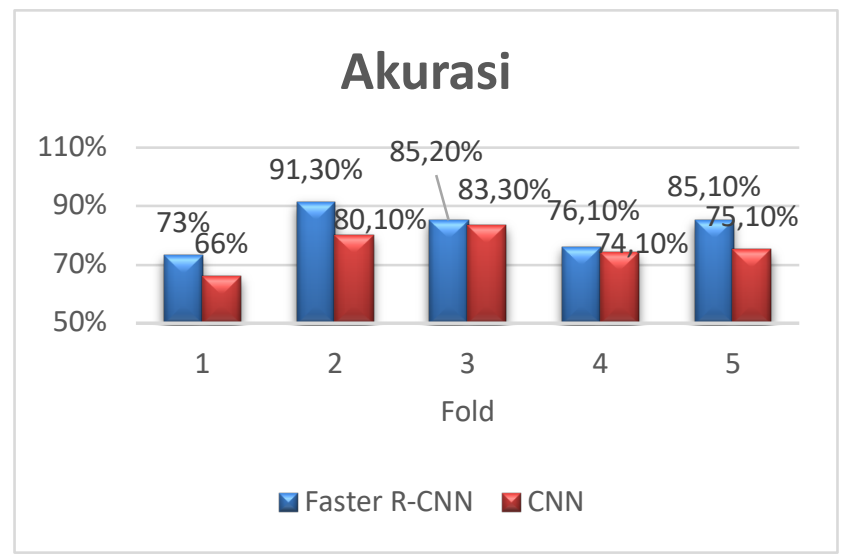

Gambar 7. Grafik hasil Pengujian Akurasi

Akurasi adalah banyaknya data yang diprediksi benar, dari seluruh dataset. Akurasi didefinisikan dari jumlah true positive dan true negative dibagi jumlah seluruh data true positive, true negative, false positive, dan false negative. Seperti terlihat pada (1)

$$
A C C=\frac{T P+T N}{T P+T N+F P+F N}
$$

Dapat dilihat pada gambar 8 bahwa algoritma deteksi objek Faster R-CNN menghasilkan presisi $91.38 \%$ untuk mengklasifikasi motif tenun melayu.

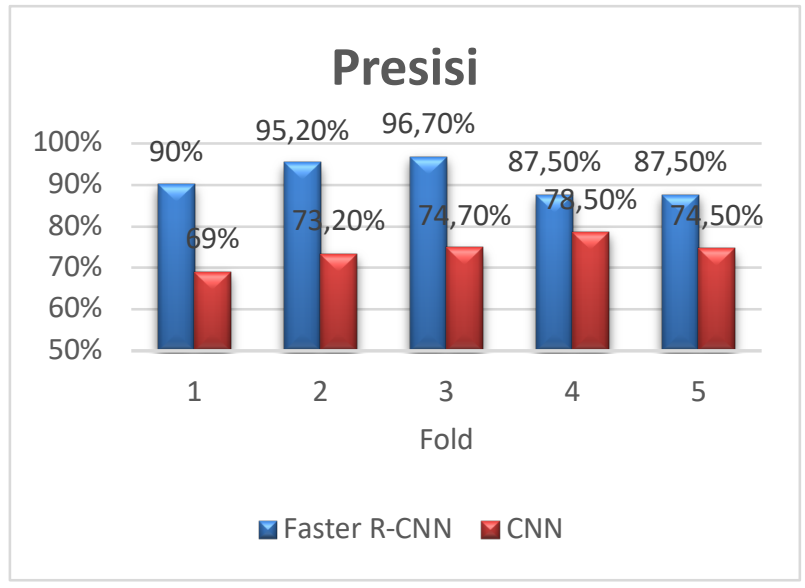

Gambar 8. Grafik hasil Pengujian Presisi

Presisi didapat dari Sebagian data yang relevan dari seluruh data pengujian yang bernilai benar. sebuah Classifier sempurna memiliki presisi bernilai 1, yang berarti $100 \%$. Presisi diambil dari jumlah data true positive dibagi dengan penjumlahan dari true positive dan false positive, seperti terlihat pada (2).

$$
\text { Prec }=\frac{T P}{T P+F P}
$$


Algoritma pendeteksi objek Faster R-CNN dapat mengklasifikasi motif tenun melayu dengan nilai recall $91.36 \%$, seperti terlihat pada gambar 9

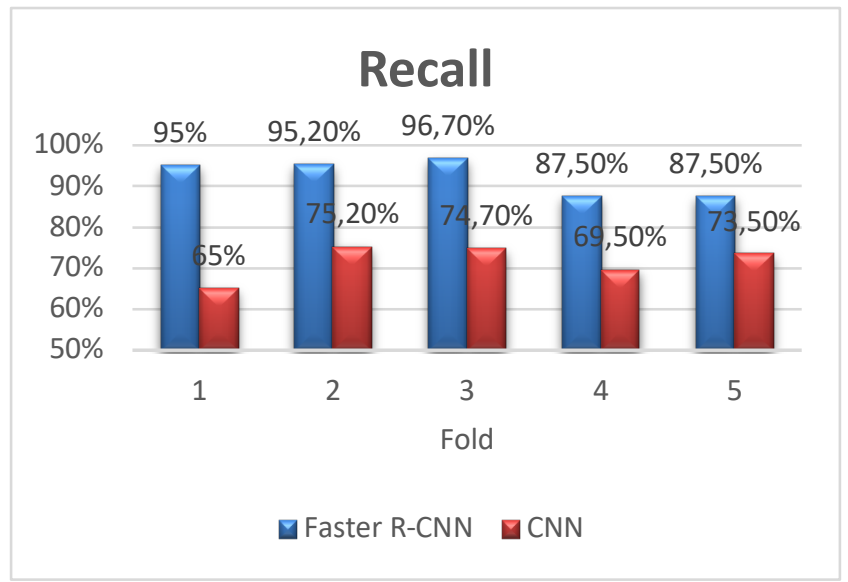

Gambar 9. Grafik hasil Pengujian recall

Recall, yang terkadang disebut sensitivity, adalah Sebagian data yang relevan dan bernilai benar dari seluruh data yang relevan. Sebuah classifier sempurna memiliki nilai recall 1, atau 100\%. Recall ditentukan dari banyaknya data true positive dibagi dengan penjumlahan true positive dan false negative, seperti pada (3)

\subsection{Pembahasan}

$$
\text { Recall }=\frac{\mathrm{TP}}{\mathrm{TP}+\mathrm{FN}}
$$

Dapat dilihat pada hasil penelitian bahwa Faster R-CNN dengan arsitektur VGG mengungguli performa algoritma lain dengan objek penelitian yang serupa, yaitu CNN dengan arsitektur AlexNet. Setelah melakukan Analisa singkat, diketahui bahwa pemilihan arsitektur sangat berpengaruh pada performa, karena dapat dilihat pada [14] bahwa perbedaan arsitektur akan mempengaruhi hasil mean Average Precision (mAP), sementara pemilihan algoritma pun juga berpengaruh kecil terhadap akurasi deteksi. Pada [20] dapat dilihat bahwa dari pengukuran validation error untuk kedua kategori, VGG mendapatkan secara berurutan $40.04 \%$ and $60.99 \%$ error yang lebih rendah daripada AlexNet. Penelitian yang dilakukan oleh [24] juga memperlihatka bahwa dari semua dataset yang bahwa Faster R-CNN unggul tidak lebih dari 3.2\% dari algoritma lain yang menggunakan selective search.

\section{KESIMPULAN}

Berdasarkan hasil penelitian yang telah dilakukan, diperoleh kesimpulan bahwa dari data latih yang berupa citra motif kain tenun melayu, didapatkan bahwa score rata-rata nilai training loss dari epoch pertama hingga epoch terakhir adalah 1,915. Klasifikasi karakteristik pengenalan motif tenun melayu menggunakan Metode deteksi objek Faster Region-based Convolutional neural network (Faster R-CNN) menggunakan arsitektur VGG melalui validasi $K$-Fold Cross Validation dengan nilai $\mathrm{k}=5$ didapatkan akurasi $82.14 \%$, presisi $91.38 \%$ dan recall $91.36 \%$. Dari Analisa ditemukan bahwa Faster R-CNN dengan VGG secara keseluruhan unggul dibandingkan algoritma lain yang meneliti objek serupa yaitu CNN dengan arsitektur AlexNet. keunggulan Faster R-CNN dari algoritma lain dipengaruhi perbedaan arsitektur yang digunakan dan sedikit dipengaruhi oleh pemilihan algoritma.

\section{UCAPAN TERIMA KASIH}

Penelitian dibiayai oleh Deputi Bidang Penguatan Riset dan Pengembangan Kementerian Riset dan Teknologi / Badan Riset dan Inovasi Nasional melalui LLDIKTI Wilayah X sesuai dengan Kontrak Penelitian Nomor: 084/LL10/PF/2020 


\section{DAFTAR PUSTAKA}

[1] N. Sahara, A. Efi, R. Fitria, dan H. Hadiastuti, "DESAIN RAGAM HIAS PELAMINAN MELAYU RIAU SEBAGAI INSPIRASI INOVASI KRIYA BATIK," Gorga J. Seni Rupa, vol. 7, no. 2, hal. 246-251.

[2] L. Marifatul Azizah, S. Fadillah Umayah, dan F. Fajar, "Deteksi Kecacatan Permukaan Buah Manggis Menggunakan Metode Deep Learning dengan Konvolusi Multilayer," Semesta Tek., vol. 21, no. 2, 2018.

[3] L. E. Peterson, "K-nearest neighbor," Scholarpedia, vol. 4, no. 2, hal. 1883, 2009.

[4] W. S. Noble, "What is a support vector machine?," Nat. Biotechnol., vol. 24, no. 12, hal. $1565-1567,2006$.

[5] T. G. Dietterich, "Ensemble learning," Handb. brain theory neural networks, vol. 2, hal. 110 $125,2002$.

[6] M. W. Gardner dan S. R. Dorling, "Artificial neural networks (the multilayer perceptron) - a review of applications in the atmospheric sciences," Atmos. Environ., vol. 32, no. 14-15, hal. 2627-2636, 1998.

[7] H. Fonda, "KLASIFIKASI BATIK RIAU DENGAN MENGGUNAKAN CONVOLUTIONAL NEURAL NETWORKS (CNN)," J. Ilmu Komput., vol. 9, no. 1, hal. 7-10, 2020.

[8] R. Girshick, J. Donahue, T. Darrell, dan J. Malik, "Region-based convolutional networks for accurate object detection and segmentation," IEEE Trans. Pattern Anal. Mach. Intell., vol. 38 , no. 1, hal. 142-158, 2015.

[9] R. Girshick, "Fast r-cnn," in Proceedings of the IEEE international conference on computer vision, 2015, hal. 1440-1448.

[10] S. Ren, K. He, R. Girshick, dan J. Sun, "Faster R-CNN: Towards Real-Time Object Detection with Region Proposal Networks," in Advances in Neural Information Processing Systems 28, C. Cortes, N. D. Lawrence, D. D. Lee, M. Sugiyama, dan R. Garnett, Ed. Curran Associates, Inc., 2015, hal. 91-99.

[11] J. Redmon, S. Divvala, R. Girshick, dan A. Farhadi, "You only look once: Unified, real-time object detection," in Proceedings of the IEEE conference on computer vision and pattern recognition, 2016, hal. 779-788.

[12] J. Redmon dan A. Farhadi, "Yolov3: An incremental improvement," arXiv Prepr. arXiv1804.02767, 2018.

[13] W. Liu et al., "Ssd: Single shot multibox detector," in European conference on computer vision, 2016, hal. 21-37.

[14] J. Huang et al., "Speed/accuracy trade-offs for modern convolutional object detectors," in Proceedings of the IEEE conference on computer vision and pattern recognition, 2017, hal. 7310-7311.

[15] R. Mawan, "Klasifikasi motif batik menggunakan Convolutional Neural Network," JNANALOKA, hal. 45-50, 2020.

[16] H. Wijayanto, "Klasifikasi Batik Menggunakan Metode K-Nearest Neighbour Berdasarkan Gray Level Co-Occurrence Matrices ( GLCM ),"Jur. Tek. Inform. FIK UDINUS, 2015.

[17] I. P. G. S. Andisana, M. Sudarma, dan I. M. O. Widyantara, "Pengenalan Dan Klasifikasi Citra Tekstil Tradisional Berbasis Web Menggunakan Deteksi Tepi Canny, Local Color Histogram Dan Co-Occurrence Matrix," Maj. Ilm. Teknol. Elektro, 2018.

[18] R. Wiryadinata, M. R. Adli, R. Fahrizal, dan R. Alfanz, "Klasifikasi 12 Motif Batik Banten 
Menggunakan Support Vector Machine,”J. EECCIS, vol. 13, no. 1, hal. 60-64, 2019.

[19] P. Aryasuta Wicaksana, I. M. Sudarma, dan D. Care Khrisne, "PENGENALAN POLA MOTIF KAIN TENUN GRINGSING MENGGUNAKAN METODE CONVOLUTIONAL NEURAL NETWORK DENGAN MODEL ARSITEKTUR ALEXNET," J. SPEKTRUM; Vol 6 No 3 J. SPEKTRUM, 2019.

[20] K. Simonyan dan A. Zisserman, "Very deep convolutional networks for large-scale image recognition," arXiv Prepr. arXiv1409.1556, 2014.

[21] R MEHINDRA PRASMATIO, B. Rahmat, dan I. Yuniar, "DETEKSI DAN PENGENALAN IKAN MENGGUNAKAN ALGORITMA CONVOLUTIONAL NEURAL NETWORK," $J$. Inform. dan Sist. Inf., vol. 1, no. 2 SE-Articles, hal. 510-521, Jul 2020.

[22] A. Santoso dan G. Ariyanto, "Implementasi Deep Learning Berbasis Keras Untuk Pengenalan Wajah," Emit. J. Tek. Elektro, vol. 18, no. 01, hal. 15-21, 2018.

[23] J. Ludwig, "Image convolution," Portl. State Univ., 2013.

[24] S. Ren, K. He, R. Girshick, dan J. Sun, "Faster R-CNN: Towards Real-Time Object Detection with Region Proposal Networks," IEEE Trans. Pattern Anal. Mach. Intell., 2017.

[25] J. S. Asri dan G. Firmansyah, "Implementasi Objek Detection Dan Tracking Menggunakan Deep Learning Untuk Pengolahan Citra Digital,” Knsi 2018, hal. 717-723, 2018.

\section{BIOGRAFI PENULIS}

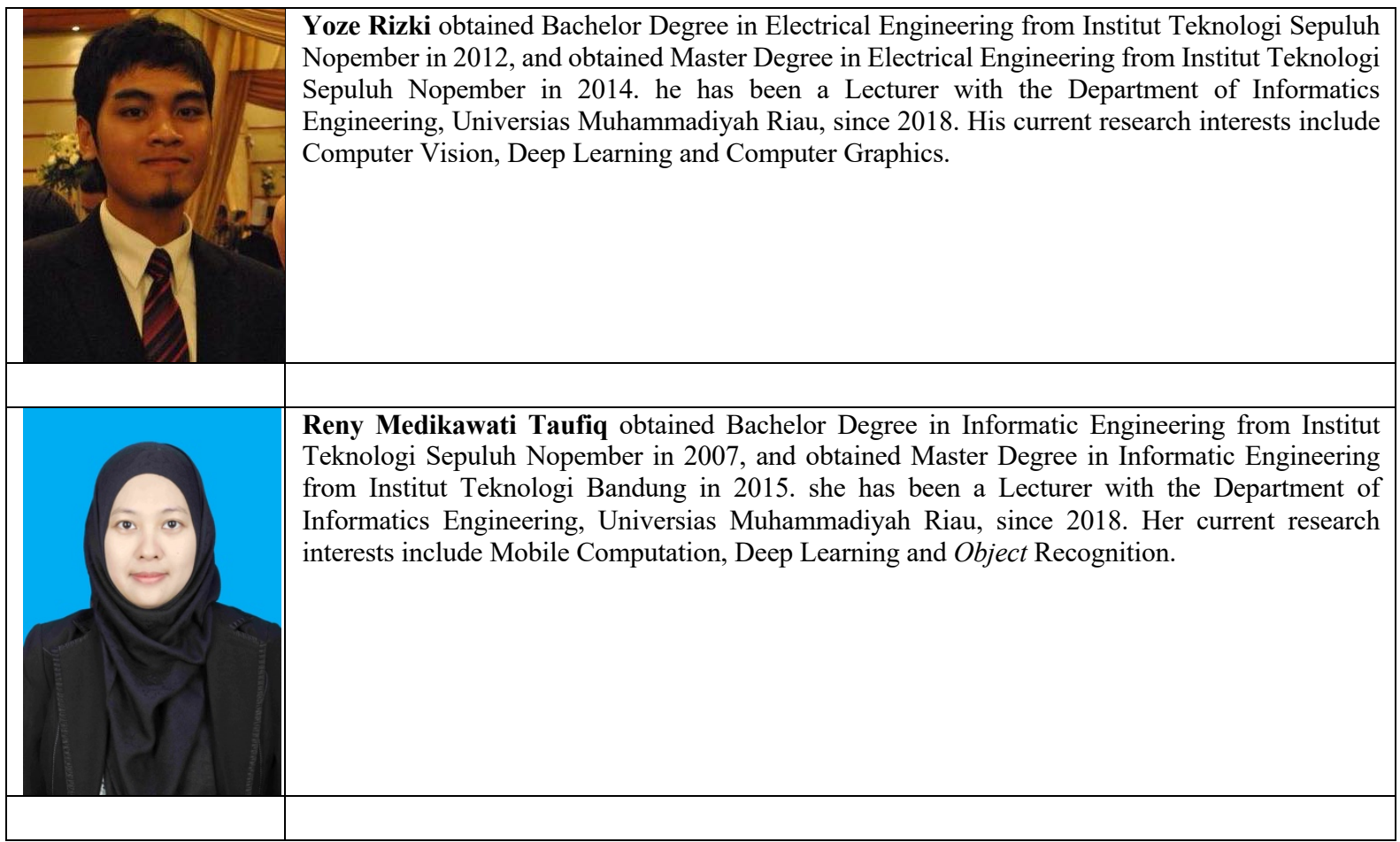


IT Jou Res and Dev, Vol.5, No.2, Maret $2021: 215$ - 225

Dinia Putri obtained Bachelor Degree in Informatic Engineering from Universitas
Muhammadiyah Riau in 2019. Her current research interests include Computer Vision, Deep
Learning and Cryptography.

